\title{
The Indicators of Psychological Resources Actualization
}

\section{Показники актуалізованості психологічних ресурсів}

\author{
Olena Shtepa \\ Ph.D. in Psychology, \\ Assistant Professor \\ Олена Штепа \\ кандидат психологічних наук, \\ доцент \\ E-mail: Olena.Shtepa@lnu.edu.ua \\ orcid.org/0000-0002-5396-3279 \\ Researcher ID: S-9557-2018
}
Ivan Franko National University
Львівський національний
of Lviv, Lviv, Ukraine університет ілені Івана
1, Universytetska str., Франка, м. Львів, Україна
Lviv, 79000 вул. Університетська, 1, м. Львів, 79000

Original manuscript received February 02, 2019

Revised manuscript accepted February 28, 2019

\begin{abstract}
The problem of uncertainty of indicators of psychological resources actualization, as a psychological state, characterizing the completeness of a certain stage, the phase of self-fulfillment is defined in the article. It is stated, that the problem of revealing the indicators of psychological resources actualization is caused by the empirical uncertainty of the coordinates of general and particular units in the system of human relations, while solving this problem will make it possible to determine the constructiveness of personality-based development. According to the results of correlation, multifactor, classification, regression analysis, it is proved, that it is reasonable to characterize the relationship between coherence, self-efficacy, systemic reflection, believe in good,
\end{abstract}


creativity, knowledge of their resources, ability to update and invest, as an indicator of psychological resources actualization. It is advisable to single out the components of the external and internal configuration of the individual respectively coherence, self-efficacy, systemic reflection and the resources of believe in good, creativity, knowledge of their resources, the ability to update and invest them. Knowledge of resources is a determinant for all components of the external and internal configuration of the personality. At the same time, this knowledge should not be self-constructed, but achieved through self-transcendence. The state of psychological resources actualization is characterized as the awareness of the personality of a new measure of spiritual tension, caused by the renewal of its knowledge of the regarding correlation of its own abilities and capabilities.

Key words: indicators of psychological resources actualization, self-efficacy, the sense of coherence, systemic reflection.

\section{Вступ}

У роботі з психологічними ресурсами особистості можна виокремити декілька важливих компонентів, серед яких найголовнішими є уміння людини оперувати власними ресурсами та їх актуалізованість. У науковій літературі докладно схарактеризовано актуалізацію як процес, водночас актуалізованість як психологічний стан, який означує завершеність певного етапу, фрази самоздійснення, не було схарактеризовано. Неозначеність актуалізованості утруднює оцінку конструктивності процесу актуалізування ресурсів, що пов'язаний із саморозвитком особистості (Кузікова, 2010: 373), оскільки дослідниками встановлено, що саморозвиток як особистісна динаміка може реалізовуватись за двома напрямами: за напрямом прагнення новизни і за напрямом значущих самоперетворень, який i є конструктивним (Трофимова, 2010: 43, 44).

Метою актуалізації ресурсів вважають розкриття можливостей особи, за якого вона набуде здатності «зустрітися iз собою» i вирішити, чи наважуватися бути справжньою собою, тобто здійснитися. Зокрема, А. Маслоу (Maslow, 1965: 111) було визначено актуалізацію як самоактуалізацію, що являє собою неперервний процес вибору людиною 
між страхом відбуватися і зростанням над собою. Науковцями зауважено, що актуалізація передбачає самоподолання і свободу вибору (Савчин, 2013: 168, 180). Відтак, можна припустити, що актуалізованість ресурсів може характеризувати досягнення людиною духовного стану свободи вибору бути більш справжньою собою. Такий стан досягається рефлексуванням, що підтверджують дані досліджень щодо зумовленості актуалізації ресурсів саморозвитку особистості рівнем її рефлексивності (Зімовін, 2014: 11). Протилежним до сконцентрованості людини на власному саморозвитку визначають екстенсивний спосіб проживання власного життя, що зумовлює виснаження ресурсів людини (Ткачев, 2018: 32).

Водночас дослідниками зауважено, що актуалізація внутрішніх можливостей є ефектом самотрансценденції (Эпштейн, 2001). Це дає підстави простежкити актуалізованість ресурсів людини у їі здатності координувати нагальні власні дії у конкретній ситуації з перспективою подальших можливих подій, що знаходить своє пояснення в ідеї узгодженості часткового із загальним і впливу на нього (Ткачев, 2018: 32). Зважаючи на думку В. Знакова щодо того, що «людина не просто реагує на ситуацію, а визначає їі, одночасно самовизначаючись» (Знаков, 2010: 108), можемо уточнити, що і життєва ситуація, і ширший за неї контекст життя є системою координат, вибудованих самою особою. Це висловлювання підтверджено теоретичною розвідкою Н. Савелюк (2015: 65), у якій особистість охарактеризовано «контекстом розуміння». Вважаємо, що розуміння людиною зв' язку нагальної ситуації та її життя загалом здійснюється у спосіб рефлексування шляхом означування себе через чуття самоефективності й когерентності.

Чуття когерентності у салютогенетичній концепції А. Антоновскі визначається здатністю особи узгоджувати нові обставини життя з минулими фактами досвіду; динамічність цього чуття зумовлена співвідношенням стимулів-викликів зовнішнього і внутрішнього досвіду людини 
та власними ресурсами, які особистість готова вкласти у розтлумачення для себе складної ситуації, яку прагне збагнути (Antonovski, 1993: 729). У теорії самоефективності А. Бандури більшою мірою йдеться про переконаність людини у здатності зарадити собі щодо розв'язання певного завдання у конкретній ситуації (Bandura, 1977). Можна припустити, що рефлексивне самовизначення людиною через зіставлення себе як самоефективної і когерентної супроводжуватиметься значною внутрішньою напругою. Дослідниками зауважено, що така напруга є виявом «роботи» внутрішніх ресурсів (Фахрутдинова, 2013: 456). Екзистенціальним психологом Р. Меєм духовну напругу включено до головних характеристик особистості та підкреслено, що динаміка особистості виявляється саме у прагненні нового духовного напруження (Мей, 2010: 34, 58). Вважаємо, що характеристика духовної напруги як самовизначення особистості саме в інтенсивний спосіб доцільно схарактеризувати з погляду теорії балансу Ф. Хайдера (Heider, 1958: 11), що дає змогу тлумачити умови і чинники змін у системі ставлень людини.

Отже, проблема з'ясування показників актуалізованості психологічних ресурсів зумовлена емпіричною невизначеністю координат загального і часткового у системі ставлень людини, водночас її розв'язання дасть змогу визначати конструктивність особистісного саморозвитку.

Мета статті - емпірично визначити показники актуалізованості психологічних ресурсів.

\section{Завдання статті}

У статті представлено теоретичну екстраполяцію координат загального і часткового у системі ставлень особистості через такі категорії самовизначення, як когерентність і самоефективність, що уможливило визначення показників актуалізованості психологічних ресурсів емпіричним способом. 


\section{Методи та методики дослідження}

Для досягнення мети емпіричного дослідження було застосовано модель дослідження Бейєра, що акцентує на перетворенні проблеми в уможливлений для її розв'язання формат і на застосуванні результатів.

Головним методом аналізу проблеми показників актуалізованості психологічних ресурсів ми визначили метод тріангуляції, що полягає у співвіднесенні результатів здійсненого нами емпіричного дослідження з теоретичною ідеєю В. Ткачова (2018: 32) щодо узгодженості часткового із загальним і впливу на нього, а також інтерпретації результатів згідно з теорією балансу Ф. Хайдера (Heider, 1958: 11).

У дослідженні ми спирались на означення особистості як актуалізації життєвого процесу в незалежній індивідуальності, яка є соціально інтегрованою та характеризується духовним напруженням (Мей, 2010: 34). Психологічні ресурси особистості нами визначено як екзистенціальнокогнітивні коди інтерпретації людиною значущості події.

Теоретичне припущення дослідження полягало у визначенні показниками актуалізованості психологічних ресурсів особистості наявності зв'язку між такими конфігураціями особистості як відкритої складної самоорганізованої системи, як рефлексивне ставлення людини до конкретної ситуації у життєвому контексті й уміння особи оперувати власними психологічними ресурсами. Актуалізованість психологічних ресурсів припущено індикатором завершеності розвитку системи на попередньому рівні іï функціонування і готовності до переходу на наступний, що виявлятиметься як духовне напруження та може бути інтерпретовано у понятті незбалансованості системи.

Перетворення проблеми в уможливлений для її розв'язання формат було здійснено методом екстраполяції координат загального і часткового у системі ставлень особистості у такі категорії самовизначення особистості, як когерентність і самоефективність, а самовизначення осо- 
би одночасно з означенням життєвої ситуації, у якій вона є, - операціоналізовано поняттям системної рефлексії. До зовнішньої конфігурації особистості як відкритої складної самоорганізованої системи віднесено відношення системної рефлексії, когерентності, самоефективності, до внутрішньої - взаємозв'язок психологічних ресурсів і показників уміння людини оперувати власними ресурсами, зокрема, знанням власних ресурсів, умінням їх оновлювати і вміщувати. Уміння особи оперувати власними ресурсами означено як психологічну ресурсність особистості (Штепа, 2018: 384).

Емпіричні гіпотези дослідження: а) якщо системна рефлексія, самоефективність, когерентність, певні психологічні ресурси і показники уміння людини оперувати власними ресурсами є індикаторами актуалізованості психологічних ресурсів, то наявним буде їх зв'язок із загальним рівнем самоактуалізації особистості; б) існуе зв'язок між системною рефлексією, самоефективністю, когерентністю, певними психологічними ресурсами і показниками уміння людини оперувати власними ресурсами; в) предиктором відношень між зовнішньою і внутрішньою конфігураціями особистості є психологічні ресурси; г) існують відмінності у рівні психологічних ресурсів осіб із різним рівнем психологічної ресурсності. 3 огляду на мету емпіричної розвідки, його важливою умовою було максимальне нівелювання відмінностей ситуації актуалізації психологічних ресурсів досліджуваних. Для реалізації цієї умови питання психодіагностичних методик були зачитані досліджуваним, а власні відповіді вони позначали у відповідному бланку. Відтак, рефлексія досліджуваних на запитання психологічних опитувальників відбулась синхронно у часі й місці дослідження.

В емпіричному дослідженні взяли участь 128 осіб (із них $86 \%$ жінки і $14 \%$ чоловіки) віком 27-55 років ( $\mathrm{M}=31,6$; $\mathrm{SD}=8,1)$ (слухачі гуманітарно-природничого факультету Інституту післядипломної та доуніверситетської підготов- 
ки спеціальностей «Українська мова та література», "Англійська мова», «Німецька мова»). До психодіагностичного інструментарію було включено шкалу рефлексивності Д. Леонтьєва, Є. Осіна (Леонтьев \& Осин, 2014: 130), загальну шкалу самоефективності Р. Шварцера (Schwarzer, 1999: 161), шкалу когерентності А. Антоновскі в адаптації Є. Осіна (Осин, 2008: 38), опитувальник самоактуалізації особистості в адаптації Нікіфорової та ін. (Никифорова та ін., 2003: 190), опитувальник психологічної ресурсності (О. Штепа, 2018: 393).

\section{Результати та дискусії}

Із метою встановлення наявності зв'язку між загальним рівнем самоактуалізації (САТ) і компонентами зовнішньої та внутрішньої конфігурації особистості як самоорганізованої системи було застосовано кореляційний аналіз. Виявлено, що існує обернений зв'язок між САТ i peсурсом віри у добро $(-0,18 ; \mathrm{p}<0,05)$, а також наявні прямі зв' язки між САТ і умінням уміщувати власні ресурси $(0,88$; $\mathrm{p}<0,01)$, когерентністю $(0,42 ; \mathrm{p}<0,01)$, самоефективністю $(0,35 ; \mathrm{p}<0,001)$, системною рефлексією $(0,18 ; \mathrm{p}<0,05)$, інтроспективною рефлексією $(-0,24 ; \mathrm{p}<0,01)$, квазірефлексією (-0,37; p < 0,01). Зв'язків САТ і ресурсу творчості на статистично значущому рівні (від р < 0,05) не встановлено. Результати здійсненого кореляційного аналізу дали змогу виокремити компоненти зовнішньої та внутрішньої конфігурації особистості як самоорганізованої системи - відповідно когерентність, самоефективність, системну рефлексію та ресурс віри у добро і показники уміння людини оперувати власними ресурсами. Ми вирішили не вилучати ресурс творчості з компонентів внутрішньої конфігурації на цьому етапі дослідження, а прийняти рішення згодом на основі розширених даних.

Із метою визначення наявності зв'язку між системною рефлексією, самоефективністю, когерентністю, психологічними ресурсами і показниками уміння людини оперува- 
ти власними ресурсами - знанням власних ресурсів, умінням їх оновлювати і вміщувати було застосовано кореляційний аналіз, результати якого наведено у табл. 1.

Таблищя 1

Кореляційні зв'язки компонентів зовнішньої та внутрішньої конфігурації особистості як самоорганізованої системи $(\mathrm{p}<0,001, \mathrm{~N}=128)$

\begin{tabular}{|c|c|c|c|c|c|c|c|c|}
\hline $\begin{array}{c}\text { Компоненти } \\
\text { зовнішньої та } \\
\text { внутрішньої } \\
\text { конфігурації } \\
\text { особистості }\end{array}$ & 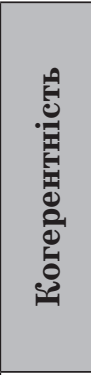 & 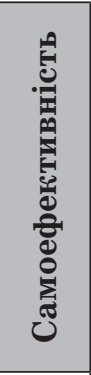 & 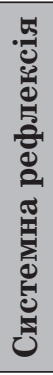 & 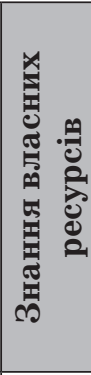 & 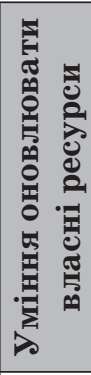 & 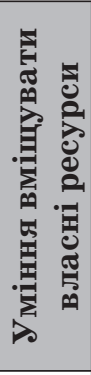 & 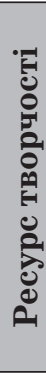 & 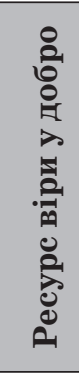 \\
\hline Когерентність & & & & & & & & - \\
\hline Самоефективність & 0,72 & - & & 0,67 & 0,84 & 0,93 & & \\
\hline Системна рефлексія & 0,52 & 0,41 & - & & & & - & \\
\hline $\begin{array}{l}\text { Знання власних } \\
\text { ресурсів }\end{array}$ & & & & - & 0,80 & & & - \\
\hline $\begin{array}{l}\text { Уміння оновлювати } \\
\text { власні ресурси }\end{array}$ & & & & & - & 0,92 & & - \\
\hline $\begin{array}{l}\text { Уміння вміщувати } \\
\text { власні ресурси }\end{array}$ & & & & & & - & - & - \\
\hline Ресурс творчості & & & & & & & - & 0,74 \\
\hline Ресурс віри у добро & & & & & & & & - \\
\hline
\end{tabular}

Результати кореляційного аналізу підтвердили наявність зв'язків між компонентами зовнішньої та внутрішньої конфігурації особистості як самоорганізованої системи. Водночас було виявлено, що ресурси творчості й віри у добро між собою корелюють прямо, а з іншими компонентами системи - обернено. Слід відзначити високий рівень коефіцієнтів кореляції самоефективності й показників уміння оперувати власними ресурсами. 
Із метою з'ясувати структуру компонентів зовнішньої та внутрішньої конфігурації особистості було застосовано багатофакторний аналіз, результати якого виявили п’ятифакторну модель конфігурації особистості як самоорганізованої системи, що у сукупності пояснювала 95,3\% дисперсії у групі досліджуваних (факторна вага > 0,7). Зокрема, до фактора 1, що пояснював 42,4\% дисперсії, увійшли такі ресурси: доброта до людей $(0,97)$, допомога іншим $(0,92)$, віра у добро $(0,86)$, робота над собою $(0,92)$, загальний рівень психологічної ресурсності $(0,86)$, когерентність $(-0,67)$; до фактора $2(25,8 \%)$ - такі ресурси, як упевненість у собі $(0,81)$, успіх $(0,79)$, показники уміння оперувати власними ресурсами - знання власних ресурсів $(0,93)$, уміння оновлювати ресурси $(0,97)$, уміння вміщувати ресурси $(0,88)$, самоефективність $(0,75)$; до фактора 3 $(12,3 \%)$ - ресурс творчості й системної рефлексії $(-0,94)$; до фактора $4(9,2 \%$,$) - інтроспективна (0,70)$ і квазірефлексія (0,97); до фактора 5 (5,6\% ) - ресурс любові $(0,70)$. Слід зауважити, що когерентність є в одному факторі з ресурсом віри у добро, самоефективність - в одному факторі з показниками умінь людини оперувати власними ресурсами, системна рефлексія - в одному факторі з ресурсом творчості. Відтак, індикаторами актуалізованості психологічних ресурсів ми визначаємо системну рефлексію, самоефективність, когерентність, психологічні ресурси творчості й віри у добро, а також показники уміння людини оперувати власними ресурсами - знанням власних ресурсів, умінням їх оновлювати і вміщувати.

Із метою визначення відношень між компонентами зовнішньої та внутрішньої конфігурації особистості було застосовано класифікаційний аналіз (табл. 2 і 3).

Наведені у табл. 2 дані дають змогу стверджувати, що зі 100\%-вою значущістю ресурс віри у добро визначає рівень когерентності, уміння вміщувати власні ресурси - самоефективність, уміння оновлювати власні ресурси - системну рефлексію. 
Таблиия 2

Результати класифікаційного аналізу предикторі зовнішньої конфігурації особистості (ранг предиктора*)

\begin{tabular}{|l|c|c|c|}
\hline \multirow{2}{*}{$\begin{array}{l}\text { Компоненти внутрішньої } \\
\text { конфігурації особистості }\end{array}$} & \multicolumn{3}{|c|}{$\begin{array}{c}\text { Компоненти зовнішньої } \\
\text { конфігурації особистості }\end{array}$} \\
\cline { 2 - 4 } & $\begin{array}{c}\text { Когерент- } \\
\text { ність }\end{array}$ & $\begin{array}{c}\text { Самоефек- } \\
\text { тивність }\end{array}$ & $\begin{array}{c}\text { Системна } \\
\text { рефлексія }\end{array}$ \\
\hline Ресурс творчості & 52 & 27 & 52 \\
\hline Ресурс віри у добро & 100 & 98 & 70 \\
\hline Знання власних ресурсів & 57 & 82 & 53 \\
\hline $\begin{array}{l}\text { Уміння оновлювати } \\
\text { власні ресурси }\end{array}$ & 79 & 85 & 100 \\
\hline $\begin{array}{l}\text { Уміння вміщувати власні } \\
\text { ресурси }\end{array}$ & 79 & 100 & 88 \\
\hline
\end{tabular}

* Ранг предиктора: 0 = найменш значущий; $100=$ найбільш значущий.

Таблиия 3

Результати класифікаційного аналізу предикторів внутрішньої конфігурації особистості (ранг предиктора*)

\begin{tabular}{|c|c|c|c|c|c|}
\hline \multirow[b]{2}{*}{$\begin{array}{c}\text { Компоненти } \\
\text { зовнішньої } \\
\text { конфігурації } \\
\text { особистості }\end{array}$} & \multicolumn{5}{|c|}{$\begin{array}{c}\text { Компоненти внутрішньої конфігурації } \\
\text { особистості }\end{array}$} \\
\hline & $\begin{array}{c}\text { Ресурс } \\
\text { твор- } \\
\text { чості }\end{array}$ & $\begin{array}{c}\text { Ресурс } \\
\text { віри у } \\
\text { добро }\end{array}$ & $\begin{array}{c}\text { Знання } \\
\text { власних } \\
\text { ресурсів }\end{array}$ & \begin{tabular}{|c} 
Уміння \\
онов- \\
лювати \\
власні \\
ресурси
\end{tabular} & \begin{tabular}{|c} 
Уміння \\
вміщу- \\
вати \\
власні \\
ресурси
\end{tabular} \\
\hline Когерентність & 100 & 100 & 94 & 100 & 95 \\
\hline Самоефективність & 46 & 93 & 100 & 88 & 100 \\
\hline Системна рефлексія & 73 & 64 & 97 & 73 & 87 \\
\hline
\end{tabular}

* Ранг предиктора: 0 = найменш значущий; $100=$ найбільш значущий.

Наведені у табл. 3 дані дають змогу стверджувати, що зі 100\% -вою значущістю когерентність визначає рівень ресурсів творчості й віри у добро, а також уміння оновлюва- 
ти ресурси, самоефективність - знання власних ресурсів i уміння їх уміщувати, системна рефлексія значною мірою зумовлює рівень знання ресурсів, водночас дещо менше, ніж самоефективність. На основі результатів класифікаційного аналізу ми припустили, що відсутність зв'язку CAT i pесурсу творчості на статистично значущому рівні можна пояснити тим, що самоактуалізація передбачає вивільнення творчого потенціалу креативності, водночас насичення ресурсу творчості зумовлене чуттям когерентності. Отже, ідеться про різні джерела творчості. Важливо звернути увагу на компоненти предикторно взаємозумовлених діад «когерентність - ресурс віри у добро» та «самоефективність - уміння вміщувати ресурси».

Iз метою визначення чинників компонентів зовнішньої та внутрішньої конфігурації особистості було застосовано регресійний аналіз ( $<0,01)$, який показав, що чинниками когерентності й самоефективності є ресурс творчості, знання ресурсів і уміння їх уміщувати; чинниками системної рефлексії є ресурс віри у добро, знання ресурсів і уміння їх уміщувати; самоефективність є чинником показників уміння оперувати власними ресурсами. Дані регресійного аналізу дали змогу уточнити, що у діаді «самоефективність уміння вміщувати ресурси» першочерговий вплив має самоефективність, тобто спочатку особа почувається здатною здолати труднощі конкретної ситуації, а після цього - докладає власні ресурси до реалізації власних цілей. Далі коло «відчуття здатності прийняти виклик - докладання ресурсів - нове відчуття здатності здолати труднощі - нове рішення щодо докладання ресурсів» стає замкненим.

Із метою визначення відмінностей у рівні психологічних ресурсів осібіз різним рівнем психологічної ресурсності було застосовано порівняльний аналіз за t-критерієм Стьюдента. Із загальної групи досліджуваних було виокремлено 18 осіб, які характеризувались рівнем психологічної ресурсності, нижчим за встановлений діагностичний рівень $(\mathrm{M}=52,4 ; \mathrm{SD}=2,79)$. Діагностичні дані цих осіб ми озна- 
чили як характеристики неактуалізованих психологічних ресурсів. Діагностичні дані інших 110 досліджуваних із рівнем психологічної ресурсності від низького до високого $(\mathrm{M}=101,0 ; \mathrm{SD}=5,04)$ було означено як характеристики актуалізованих психологічних ресурсів. У результаті порівняння означених двох підгруп за t-критерієм Стьюдента було з'ясовано, що досліджуваним, які характеризуються актуалізованими ресурсами, властивий вищий рівень ресурсів творчості, віри у добро, знання власних ресурсів, уміння їх оновлювати і вміщувати $(\mathrm{p}<0,01)$, самоефективності й системної рефлексії (p < 0,05). За рівнем когерентності відмінностей на статистично значущому рівні (від $\mathrm{p}<0,05)$ не виявлено.

Із метою характеристики особливостей зв' язків компонент зовнішньої та внутрішньої конфігурації особистості в осіб з актуалізованими і неактуалізованими психологічними ресурсами було здійснено кореляційний аналіз, результати якого унаочнено на рис. 1.

Порівняльний аналіз виявив певні особливості зв' язків компонент зовнішньої та внутрішньої конфігурації особистості в осіб з актуалізованими ресурсами, які ми проінтерпретували у межах теорії балансу системи Ф. Хайдера: 1) позитивні зв'язки між когерентністю, самоефективністю і системною рефлексією характеризують збалансованість системи зовнішньої конфігурації особистості; 2) негативні зв' язки між такими компонентами внутрішньої конфігурації особистості, як ресурси віри у добро і творчості й уміння оновлювати і вміщувати ресурси, характеризують збалансованість підсистем внутрішньої конфігурації особистості. Водночас недостатній рівень значущості зв'язку ресурсу творчості й знання ресурсів робить підсистему розімкнутою. Імовірно, це і є ознакою відкритості системи, а також ознакою того, що знання власних ресурсів особи з актуалізованими ресурсами не конструюють собі самі, а отримують через канал системної рефлексії, тобто через самотрансценденцію. 


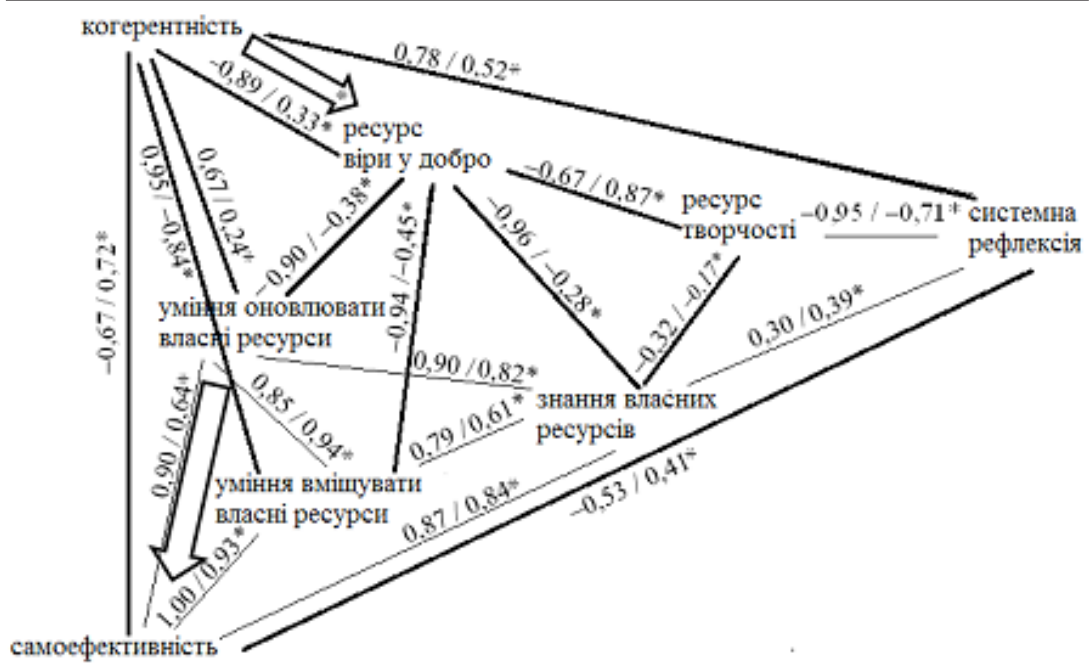

Умовні позначення:

зв'язки, що мають відмінн абсолютні величини коефіцієнтів кореляції у підгрупі осіб 3 неактуалізованими психологінними ресурсами

$0,78 / 0,52 *$ абсолютні величини коефіцієнтів кореляції у підгрупі осіб 3 актуалізованими психологінними ресурсами

$-0,17^{*}$ (показник не сягає рівня статистичної значущості $\mathrm{p}<0,05$ )

позначення чинника

Puc. 1. Особливості зв'язків компонент зовнішньої та внутрішньої конфігурації особистості в осіб з актуалізованими і неактуалізованими психологічними ресурсами $(\mathrm{p}<0,001)$

Підсистема внутрішньої конфігурації особистості, що утворюється двома позитивними зв'язками між когерентністю і ресурсом віри у добро та когерентністю й умінням оновлювати власні ресурси, а також негативним зв'язком між ресурсом віри у добро й умінням оновлювати власні ресурси, характеризується як незбалансована. Беручи до уваги, що у підгрупі осіб з актуалізованими ресурсами когерентність є чинником ресурсу віри у добро, можна 
припустити, що незбалансованість означеної підсистеми зумовлена насиченням ресурсу віри у добро (що характеризується як переконаність людини в наявності справедливості, умінні бути милосердною, умінні сподіватися, відсутності відчаю й амбівалентності) через контент когерентності; 3) незбалансована підсистема зовнішньо-внутрішніх зв'язків конфігурацій особистості «когерентність - віра у добро - уміння вміщувати ресурси» і розімкнута внутрішня підсистема «віра у добро - ресурс творчості - знання ресурсів» із високою ймовірністю зумовлюють духовну напругу. Припускаємо, що ця напруга може бути оптимальною за умови, якщо особа не починає конструювати себе чи не відмовляється від зіставлення розуміння справедливості й милосердя із загальним життєвим контекстом, який можна охарактеризувати як метанаратив.

У підгрупі осіб із неактуалізованими ресурсами наявна незбалансованість у підсистемі «когерентність - уміння оновлювати ресурси - уміння вміщувати ресурси», означена двома позитивними зв'язками й одним негативним. Для осіб із неактуалізованими ресурсами когерентність $є$ джерелом оновлення ресурсів, водночас вони не схильні вміщувати ресурси, тобто діяти згідно з мудрістю метанаративу. Саме уміння оновлювати ресурси є чинником їх самоефективності, водночас зростання самоефективності знижує їх рівень когерентності, отже, вони самі себе виснажують.

\section{Висновки}

Результати емпіричного дослідження дають підстави охарактеризувати особливості зв'язків когерентності, самоефективності, системної рефлексії, ресурсів віри у добро, творчості, знання власних ресурсів, уміння їх оновлювати і вміщувати як показник актуалізованості психологічних ресурсів особи. Доцільно виокремлювати компоненти зовнішньої та внутрішньої конфігурації особистості - відповідно когерентність, самоефективність, системну рефлек- 
сію та ресурси віри у добро і творчості й показники уміння оперувати власними ресурсами. Показники внутрішньої конфігурації особистості - ресурси - є визначальними для особистісної динаміки. Знання ресурсів є чинником усіх компонент зовнішньої та внутрішньої конфігурації особистості, водночас воно має бути не самосконструйованим, а досягнутим через самотрансценденцію.

Зв'язки між когерентністю і знанням ресурсів визначають оптимум напруги особистості як відкритої самоорганізованої системи: з одного боку, підвищення рівня знання власних ресурсів призводить до зниження рівня віри у добро, а далі - й когерентності. 3 другого боку, зі зростанням рівня знання власних ресурсів збільшується самоефективність і системна рефлексія, що далі підвищує рівень когерентності. Відтак, визначальним є джерело знань людини щодо себе самої. Несуперечливість даних системної рефлексії (самотрансценденції) і самоефективності, що властива для осіб із актуалізованими ресурсами, створює підстави для обгрунтованого знання людиною власних можливостей. Якщо дані системної рефлексії та самоефективності є взаємовиключними, що виявляється в осіб із неактуалізованими ресурсами, то знання людиною власних ресурсів є нереалістичним, а саморозвиток непродуктивним. Вважаємо що актуалізованість психологічних ресурсів доцільно охарактеризувати як усвідомлення особистістю нової міри духовної напруги, зумовленої оновленням їі знання щодо співвідношення власних здатностей і можливостей. Отже, актуалізованість психологічних ресурсів характеризує не завершеність етапу самоздійснення, а його початок.

\section{Література}

Зімовін О. І. Залежність актуалізації ресурсів саморозвитку особистості студентів від типу та рівня рефлексивності. Вісник Харківського національного університету. Серія «Психологія». 2014. № 1099. C. 9-13. URL: https://irbis-nbuv.gov.ua. 
Знаков В. В. Тезаурусное и нарративное понимание события как проблема психологии человеческого бытия. Методология и история $\mathrm{ncu}$ хологии. 2010. Вып. 3. Т. 5. С. 105-119. URL: https://mhp-journal. $\mathrm{ru}$.

Кузікова С. Б. Структурно-змістовий аналіз феномену особистісного саморозвитку. Проблели сучасної психологї: зб. наук. праць Кал’янець-Подільського національного університету ілені Івана Огієнка, Інституту психологї̈ іл. Г. С. Костюка АПН України / За ред. С. Д. Максименка, Л. А. Онуфрієвої. Кам'янець-Подільський : Аксіома, 2010. Вип. 10. С. 365-377.

Леонтьев Д. Психология смысла. Природа, строение и динамика смысловой реальности. 3-е изд. Москва : Смысл, 2007.

Леонтьев Д., Осин Е. Рефлексия «хорошая» и «дурная»: от объяснительной модели к дифференциальной диагностике. Психология. Журнал Высшей школь эконолики. 2014. Т. 11. № 4. С. 110-135.

Мэй Р. Искусство психологического консультирования. Как давать и обретать душевное здоровье [пер. с англ.]. Москва : Институт общегуманитарных исследований; Апрель Пресс, 2010.

Никифорова Г. С., Дмитриева М. А., Снеткова В. М. (Ред.). Практикум по психологии менеджмента и профессиональной деятельности. Санкт-Петербург : Речь, 2003.

Осин Е. Н. Чувство связности как показатель психологического здоровья и его диагностика. Психологическая диагностика. 2007. № 3. C. 22-40. URL: https://rsfdgrc.hse.ru.

Савелюк Н. М. Контекст як системний чинник розуміння дискурсу: філософські, лінгвістичні та психологічні аспекти. Науковий вісник Херсонського державного університету. Серія «Психологічні науки». 2015. Вип. 1. T. 1. С. 61-65. URL: https://irbis-nbuv.gov. ua/UJRN/nvkhp_2015_1.

Савчин М. Духовна парадигма психології: монографія. Київ : «Академвидав», 2013.

Ткачев Андрей, протоиерей. Бремя страстей. Тайная жизнь наших душ. Киев : «Послушник», 2018.

Трофимова Ю. В. Два подхода к пониманию саморазвития как психологического феномена. Педагогика и психология. 2010. С. 42-46. URL: https://izvestia/asu/ru.

Фахрутдинова Л. Р. Переживание, впечатление и духовный опыт. Человек, субъект, личность в совреленной психологии. Материаль Международной конферениии, посвященной 89-летию А. В. Брушлинского / Отв. ред. А. Л. ЖЖуравлев, Е. А. Мергтенко. Москва : Изд-во «Институт психологии РАН», 2013. Т. 1. С. 455-457.

Штепа О. С. Опитувальник психологічної ресурсності особистості: результати розробки й апробації авторської методики. Проблели 
сучасної психології: зб. наук. праць Кал'янець-Подільського національного університету ілені Івана Огієнка, Інституту психологї̈ імені Г. С. Костюка НАПН України / За наук. ред. С. Д. Максименка, Л. А. Онуфрієвої. Кам' янець-Подільський : Аксіома, 2018. C. 380-399. URL: https://nbuv.gov.ua/UJRN/Pspl_2018_39_33.

Эпштейн М. Н. Философия возможного. Возможное как сущее. 2001. URL: http://society.polbu.ru/epstein_possiblephilo/ch01_i.html.

Antonovski, A. (1993). The structure and properties of the sense of coherence scale. Soc Sci Med, 36 (6), 725-733. Retrieved from https:// doi.org/10.1016/0277-9536(93)90022-Z.

Bandura, A. (1997). Self-efficacy: toward a unifying theory of behavioral change. Psychological review, 84 (2), 191-215. Retrieved from https://psynet/apa.org.

Heider, F. (1958). The Psychology of Interpersonal Relations. New York : John Wiley \& Sons. Retrieved from http://dx.doi.org/10.1037/ 10628-000.

Maslow, A. (1965). Self-actualization and beyond. Conference on the training of counselors of adults, may 22-28, 111-131. Massachusetts : Chatham.

Schwarzer, R., Muller, J., \& Greenglass, E. (1999). Assessment of perceived general self-efficacy on the Internet: data collection in cyberspace. Anxiety, Stress, and Coping, 12, 145-161. Retrieved from URL: https://userpage.fu-berlin.de.

\section{References}

Zimovin, O. I. (2014). Zalezhnist aktualizatsii resursiv samorozvytku osobystosti studentiv vid typu ta rivnia refleksyvnosti [Dependence of actualization of self-development resources of students' personality from the type and level of reflexivity]. Visnyk Kharkivskoho natsionalnoho universytetu. Seriia "Psykholohiia» - Bulletin of Kharkiv National University. Series «Psychology», 1099, 9-13. Retrieved from https://irbis-nbuv.gov.ua [in Ukrainian].

Znakov, V. V. (2010). Tezaurusnoe i narrativnoe ponimanie sobytija kak problema psihologii chelovecheskogo bytija [The thesaurusly and narratively understanding of the event as a problem of person being]. Metodologija i istorija psihologii - Methodology and history of psychology, 3, T. 5, 105-119. Retrieved from https://mhp-journal.ru [in Russian].

Kuzikova, S. B. (2010). Strukturno-zmistovyi analiz fenomenu osobystisnoho samorozvytku [Structural and content analysis of the phenomenon of personal self-development]. S. D. Maksymenko, L. A. Onufriieva (Eds.). Problemy suchasnoi psykholohii - Problems of modern psychology: Collection of research papers of Kamianets-Podilskyi 
National Ivan Ohiienko University, G. S. Kostiuk Institute of Psychology of the National Academy of Educational Sciences of Ukraine, 10, 365-377. Kamianets-Podilskyi : Aksioma [in Ukrainian].

Leont'ev, D. (2007). Psihologija smysla. Priroda, stroenie i dinamika smyslovoj real'nosti [Psychology of meaning. Nature, structure and dynamics of meaning reality]. (3rd ed.). Moskva : Smysl [in Russian].

Leont'ev, D., \& Osin, E. (2014). Refleksija «horoshaja» i «durnaja»: ot ob'jasnitel'noj modeli k differencial'noj diagnostike [«Good» and «Bad» Reflection: From an Explanatory Model to Differential Assessment]. Psihologija. Zhurnal Vysshej shkoly jekonomiki - Psychology. Journal of Higher School of Economics, 4, T. 11, 110-135 [in Russian].

Mjey, R. (2010). Iskusstvo psihologicheskogo konsul'tirovanija. Kak davat' $i$ obretat' dushevnoe zdorov'e [The art of counseling. How to give and gain the mental health] (Transl. from Engl.). Moskva : Institut obshchegumanitarnyh issledovanij; Aprel' Press [in Russian].

Nikiforova, G. S., Dmitrieva, M. A., \& Snetkova, V. M. (Eds.) (2003). Praktikum po psihologii menedzhmenta $i$ professional'noj dejatel'nosti [Workshop on the psychology of management and professional activities ]. Sankt-Peterburg : Rech' [in Russian].

Osin, E. (2007). Chuvstvo svjaznosti kak pokazatel' psihologicheskogo zdorov'ja i ego diagnostika [The the sense of coherence as an indicator of psychological health and its diagnostics]. Psihologicheskaja diagnostika - Psychological diagnostics, 3, 22-40. Retrieved from https://rsfdgrc.hse.ru [in Russian].

Saveliuk, N. M. (2015). Kontekst yak systemnyi chynnyk rozuminnia dyskursu: filosofski, linhvistychni ta psykholohichni aspekty [Context as a systemic factor of understanding discourse: philosophical, linguistic and psychological aspects]. Naukovyi visnyk Khersonskoho derzhavnoho universytetu. Seriia "Psykholohichni nauky" - Scientific Newsletter of Kherson State University. Series «Psychological Sciences», 1, T. 1,61-65. Retrieved from https://irbis-nbuv.gov.ua/ UJRN/nvkhp_2015_1[in Ukrainian].

Savchyn, M. (2013). Dukhouna paradyhma psykholohii [The spiritual paradigm of psychology]. Kyiv : «Akademvydav» [in Ukrainian].

Tkachev, Andrej, protoierej (2018). Bremja strastej. Tajnaja zhizn' nashih dush [Burden of passion. The secret life of our souls]. Kiev : "Poslushnik» [in Russian].

Trofimova, Ju. V. (2010). Dva podhoda k ponimaniju samorazvitija kak psihologicheskogo fenomena [Two approaches to understanding self-development as a psychological phenomenon]. Pedagogika i psihologija - Pedagogy and Psychology, 42-46. Retrieved from https:// izvestia/asu/ru [in Russian]. 
Fahrutdinova, L. R. (2013). Perezhivanie, vpechatlenie i duhovnyj opyt [Experience, impression and spiritual experience]. Chelovek, sub'ekt, lichnost' $v$ sovremennoj psihologii. Materialy Mezhdunarodnoj konferencii, posvjashchennoj 89-letiju A. V. Brushlinskogo. A. L. Zhuravlev, E.A. Mergtenko (Eds.) - Man, subject, personality in modern psychology. Proceedings of the International Conference dedicated to the 89th anniversary of $A$. V. Brushlinsky, T. 1, 455-457. Moskva : Izd-vo «Institut psihologii RAN» [in Russian].

Shtepa, O. S. (2018). Opytuvalnyk psykholohichnoi resursnosti osobystosti: rezultaty rozrobky i aprobatsii avtorskoi metodyky [The questionnaire of a personality's psychological resourcefulness: the results of development and approbation of the author's method]. S. D. Maksymenko, L. A. Onufriieva(Eds.). Problemy suchasnoi psykholohii-Problems of Modern Psychology. Collection of research papers of Kamianets-Podilskyi National Ivan Ohiienko University, G. S. Kostiuk Institute pf Psychology of the National Academy of Educational Sciences of Ukraine, 39, 380-399. Kamianets-Podilskyi: Aksioma [in Ukrainian]. Jepshtejn, M. N. (2001). Filosofija vozmozhnogo. Vozmozhnoe kak sushchee [The philosophy of the possible. A Possibility as a being]. Retrieved from http://society.polbu.ru/epstein_possiblephilo/ch01_i.html [in Russian].

Antonovski, A. (1993). The structure and properties of the sense of coherence scale. Soc Sci Med, 36 (6), 725-733. Retrieved from https:// doi.org/10.1016/0277-9536(93)90022-Z.

Bandura, A. (1997). Self-efficacy: toward a unifying theory of behavioral change. Psychological review, 84 (2), 191-215. Retrieved from https://psynet/apa.org.

Heider, F. (1958). The Psychology of Interpersonal Relations. New York : John Wiley \& Sons. Retrieved from http://dx.doi.org/10.1037/ 10628-000.

Maslow, A. (1965). Self-actualization and beyond. Conference on the training of counselors of adults, may 22-28, 111-131. Massachusetts : Chatham.

Schwarzer, R., Muller, J., \& Greenglass, E. (1999). Assessment of perceived general self-efficacy on the Internet: data collection in cyberspace. Anxiety, Stress, and Coping, 12, 145-161. Retrieved from URL:https://userpage.fu-berlin.de.

\section{Штепа Олена. Показники актуалізованості психологічних ресурсів}

\section{АНОТАЦІЯ}

Окреслено проблему невизначеності показників актуалізованості психологічних ресурсів як психологічного стану, який означує завершеність 
певного етапу, фази самоздійснення. Теоретично простежено зв'язок актуалізації психологічних ресурсів із самотрансценденцією, самоефективністю, когерентністю, рефлективністю особистості. Констатовано, що проблема з'ясування показників актуалізованості психологічних ресурсів зумовлена емпіричною невизначеністю координат загального і часткового у системі ставлень людини, водночас ії розв'язання дасть змогу визначати конструктивність особистісного саморозвитку. Метою дослідження було емпірично визначити показники актуалізованості психологічних ресурсів. Для досягнення мети емпіричного дослідження було застосовано модель дослідження Бейєра та метод тріангуляції. В емпіричному дослідженні взяли участь 128 осіб віком 27-55 років. 3 огляду на мету емпіричної розвідки, ї̈ важливою умовою було максимальне нівелювання відмінностей ситуації актуалізації психологічних ресурсів досліджуваних, що було досягнуто організацією ходу психологічного опитування. За результатами кореляційного, багатофакторного, класифікаційного, регресійного аналізу обгрунтовано, що показником актуалізованості ресурсів доцільно характеризувати особливості зв'язків когерентності, самоефективності, системної рефлексії, ресурсів віри у добро, творчості, знання власних ресурсів, уміння їх оновлювати і вмішувати. Доцільно виокремлювати компоненти зовнішньої та внутрішньої конфігурації особистості - відповідно когерентність, самоефективність, системну рефлексію та ресурси віри у добро і творчості й показники уміння оперувати власними ресурсами. Показники внутрішньої конфігурації особистості - власне психологічні ресурси - $є$ визначальними для особистісної динаміки. Знання ресурсів $\epsilon$ чинником усіх компонент зовнішньої та внутрішньої конфрігурації особистості, водночас воно має бути не самосконструйованим, а досягнутим через самотрансценденцію. Зв'язки між когерентністю і знанням ресурсів визначають оптимум напруги особистості як відкритої самоорганізованої системи. Актуалізованість психологічних ресурсів охарактеризовано як усвідомлення особистістю нової міри духовної напруги, зумовленої оновленням ії знання щодо співвідношення власних здатностей і можливостей. Відтак, актуалізованість психологічних ресурсів характеризує не завершеність етапу самоздійснення, а його початок.

Ключові слова: показники актуалізованості психологічних ресурсів, психологічні ресурси, самоефективність, когерентність, системна рефлексія. 
Штепа Елена. Показатели актуализованности психологчческих ресурсов

\section{АННОТАЦИЯ}

Определена проблема неопределенности показателей актуализованности психологических ресурсов как психологического состояния, характеризующего завершенность некоторого этапа, фразы самоосуществления. Теоретически прослежена связь актуализации психологических ресурсов с самотрансценденцией, самоэффрективностью, когерентностью, рефлексивностью личности. Констатировано, что проблема раскрытия показателей актуализованности психологических ресурсов обусловлена эмпирической неопределенностью координат общего и частного в системе отношений человека, в то же время решение этой проблемы даст возможность определять конструктивность личностного развития. Целью исследования было эмпирически определить показатели актуализованности психологических ресурсов. Для достижения цели эмпирического исследования была применена модель Бейєра и метод триангуляции. В исследовании приняли участие 128 человек 27-55 лет. Учитывая цель эмпирического исследования, его важным условием было максимальное нивелирование отличий ситуации актуализации психологических ресурсов, что было достигнуто организацией хода психологического опроса. На основе результатов корреляционного, многофакторного, классификационного, регрессионного анализа обосновано, что показателем актуализованности психологических ресурсов челесообразно охарактеризовать особенности взаимосвязи когерентности, самоэффективности, системной рефлексии, ресурсов веры в добро, творчества, знания своих ресурсов, умения их обновлять и вкладывать. Целесообразно выделять компоненты внешней и внутренней конфигурации личности - соответственно когерентность, самоэфрективность, системную рефлексию и ресурсы веры в добро, творчества, знание своих ресурсов, умение их обновлять и вкладывать. Показатели внутренней конфигурации личности - собственно психологические ресурсы - являются определяющими для личностной динамики. Знание ресурсов является детерминантой для всех компонент внешней и внутренней конфигурации личности. В то же время, это знание не должно быть самосконструированным, а достигнутым через самотрансценденцию. Связи между когерентностью и знанием ресурсов определяют оптимум напряжения личности как открытой самоорганизующейся системы. Актуализованность 
психологических ресурсов охарактеризовано как осознание личностью новой меры духовного напряжения, обусловленного обновлением ее знания относительно соотношения собственных способностей и возможностей. Соответственно, актуализованность психологических ресурсов характеризует не завершенность этапа самоосуществления, а его начало.

Ключевые слова: показатели актуализованности психологических ресурсов, психологические ресурсы, самоэффективность, когерентность, системная рефлексия. 